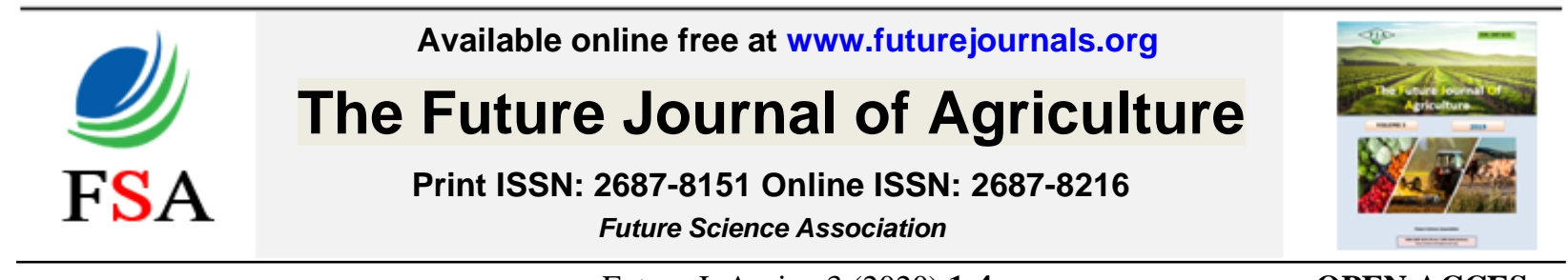

Future J. Agric., 3 (2020) 1-4

OPEN ACCES

DOI: $10.37229 /$ fsa.fja.2020.07.03

\title{
EFFECT OF GIBBERELLIC ACID (GA3) ON GROWTH AND SOME CHARACTERISTICS OF ORNAMENTAL PLANTS (Review Article)
}

\author{
Angham Talal Mahmoud AL-Chalabi \\ Department of Horticulture and Landscape, College of Agriculture and Forestry, University of Mosul, Iraq.
}

*Corresponding author: alchalabiangham@gmail.com Received: 27 May 2020 ; Accepted: 3 July 2020

\begin{abstract}
Gibberellin is one of the hormones produced by modern plant leaves and values developing in the roots and stems, and through studies on the $\mathrm{GA}_{3}$ its effect on the characteristics of the plant. The gibberellic acid was distinguished by its ability to cross the senses of many plants .and the increase in the number of leaves, the speed of the treated seed germination, the percentage of chlorophyll, the fresh and dry weight of the vegetative system.in addition to many other characteristics of added plants. It has different concentrations of this acid, especially when compared with the comparison treatment or with other substances interfering with it.
\end{abstract}

Key words: Gibberellic acid, ornamental plants, growth

\section{INTRODUCTION}

Gibberellins are described as a group of hormonal growth stimulants, and it is one of the naturally occurring hormones in plants within plant tissues, as they possess carboxyl groups, and this is why they are called gibberellic acid, and the hormonal effect and response to gibberellin vary depending on the variety and plant type, and for this we find a close relationship between the normal gibberellin level and the extent of this level change when adding or dealing with it by external gibberellin Abu Zaid (2000) and Yassin (2001). Gibberellins are an important part of the chemicals used to change the behavior and development of plants, and that one of the most important effects of gibberellin is to stimulate it to elongate the stem, especially dwarf plants, in addition to breaking the dormancy of buds and accelerating flowering (Wasfi, 1995). Among the studies that the researchers pointed out about the effect of gibberellic acid on the appearance of the internal and external plant, Emongor (2003) found in his study the effect of gibberellic acid $\mathrm{GA}_{3}$ on the quality of inflorescences after harvest and the flowering age of gerbera flowers $G$. jamesonii cultivar Ida Red, which was harvested when the outer two rows of flowers opened. For discs, inflorescences were inundated for a long time in a solution of gibberellic acid with concentrations of $0,0-2,5-5,0-7,5$ mg. $\mathrm{L}^{-1}$ The above concentrations resulted in delaying senescence, increasing the number of open flowers, delaying the pallor of radial flowers and increasing the water content of the inflorescences, thereby maintaining cell swelling and reducing curvature and senescence of inflorescences.

Among the effects of $\mathrm{GA}_{3}$ acid is its role in increasing early blooming, Kurtar and Ayan (2005) in their study on the effect of indole acetic acid and gibberellic acid at concentrations: $55,100,250$ and $500 \mathrm{mg} / \mathrm{L}^{-1}$ as well as a comparison treatment in the flowering and yield of the Tulipa gesneriana plant as a spray on the vegetative group 5 
times between sprinkles to another 7 days. the results showed that spraying with a concentration of $250 \mathrm{mg} . \mathrm{L}^{-1}$. resulted in recording the largest number of early flowers 9.10 flower. $\mathrm{m}^{2}$ and stimulating them to grow. Narong (2004) explained that the induction of flowering in the gladiolus plant is different depending on the climate. In the cold climate, it is necessary to immerse the bulbs before planting them for two weeks in a water temperature of $\left(27-32{ }^{\circ} \mathrm{C}\right)$ to force the bulbs to early flowering, but in a warm climate, soak the bulbs with a solution of gibberellin (10 - 25). mg. $\mathrm{L}^{-1}$ before planting will accelerate flowering and accelerate flower development. And gibberellic acid has a direct role in plant height, increase in leaf numbers and intensity of chlorophyll, where it was clarified. Al-Layla (2006) mentioned that the use of high concentration of gibberellic acid $300 \mathrm{mg} . \mathrm{L}^{-1}$ led to an increase in the height of the Ficus elastica plant, decora variety in comparison to the comparison treatment, number of leaves also increased expulsion with an increase in the concentration of gibberellic acid, an increase in the diameter of the stem when spraying with a concentration of $100 \mathrm{mg} . \mathrm{L}^{-1}$, as well as an increase in the content of chlorophyll. Wasfi (1995) stated that gibberellic acid works to delay the demolition of chlorophyll and increase its construction.

Gibberellic acid has an effective role in collecting the manufactured materials from the leaves and sending them to the places of growth and propagation, where the treatment with the gibberellic acid led to the early opening of the inflorescences, and this result explains the role of the acid in the polarization of the manufactured materials in the leaves and connecting them to the growth sites (Bidwell, 1979), Selim et al. (1993) mentioned that the added gibberellic acid had an effect in raising the level of the internal gibberellins, which caused the scape length. Saleh (1991) explained the effect of the gibberellic acid on stimulating the growth of axillary buds and stimulating apical dominance, and gibberellin had an effective role in the process of photosynthesis, Khattab et al. (2000 a and b) mentioned that the bulbs of gladiolus plant of immersed in the $\mathrm{GA}_{3}$ solution in concentration $(0$ and 100 mg. $\mathrm{L}^{-1}$ ) for 24 hours before implantation had an effect on photosynthesis as a result of the large amplitude of growth vegetative is good as it led to more accumulation of nutrients in the parts of storage inside the plant, as the chlorophyll content and plant height increased and the number of bulbs produced / plant increased. Gurgar (1996) indicated that spraying Croton plants with gibberellic acid with a concentration of $200 \mathrm{mg} . \mathrm{L}^{-1}$ twice during the growing season has led to an increase in the plant length, number of leaves, fresh and dry weight. It also led to an increase in the vegetative content of the major elements NPK as well as an increase in the content of the chlorophyll $\mathrm{a}$ and $\mathrm{b}$ in the leaves compared to the comparison treatment. Abdul Jaleel et al. (2008) stated that watering the soil cultivated with Catharanthus roseus 45 days after planting with gibberellic acid increased the height of the plants compared to the comparison treatment, as well as the frash and dry weight of the plant, and caused the stimulation and speed of division and elongation of the cells and thus increase the fresh and dry weight vegetative group in the plant. Kumar et al. (2008) explained that the treatment gladiolus plants with gibberellic acid increased the length and number of florets in the syphilis compared to other treatments. Al-Khuzaai (2013) observed when using gibberellic acid with organic fertilizer in some characteristics of vegetative and syphilis growth of the Tagetes erecta $\mathrm{L}$ plant as three concentrations of gibberellic acid (0 - 150 - 200) mg.L $\mathrm{L}^{-1}$ were used and three concentrations of liquid organic fertilizer $(0-2-4) \mathrm{ml}^{-\mathrm{L}^{-1}}$ where, the results showed that spraying with gibberellic acid and compost and their interaction significantly affected the characteristics of vegetative, floral and root growth, as the treatment recorded the largest values at 200 $\mathrm{mg} . \mathrm{L}^{-1}$ gibberellin with $2 \mathrm{ml} . \mathrm{L}^{-1}$ and $4 \mathrm{ml} . \mathrm{L}^{-1}$ of liquid organic fertilizer. Abdul-Razzaq $\boldsymbol{e t}$ al. (2014) stated that using gibberellic acid on the geranium plant at $300 \mathrm{mg} . \mathrm{L}^{-1}$, concentration an increase in the plant height, the number of flowering inflorescences, intensity of chlorophyll, $t$ length of flowering period, Mishra et al. (2018) explained when 
using gibberellic acid on three varieties of aster plants: Arka, Shashank Arka Archana and Aadya when grown in special growth pots in order to know the effect of the acid on number of leaves, growth and flowering, concentrations of acid were added (50 - 100 150) mg. $\mathrm{L}^{-1}$, it was found that the Arka and Adya cultivars recorded the largest values compared to the Shashank class for the characteristics of the number of leaves, the number of flowers and the number of days for the emergence of the inflorescence bud, while the Shashank cultivar recorded the largest number of primary branches when spraying with a concentration of $100 \mathrm{mg} . \mathrm{L}^{-1}$, AL-sahin (2011) indicated that spraying of dianthus caryophyllus $L$. carrots with $\mathrm{GA}_{3}$ gave the highest stem length, leafy area and leaf content of chlorophyll, as well as the dry weight of the vegetative group and the leaf content of total carbohydrates, flower stalk length and flowers diameter. Hussein (1985) and Hopkins (1999) stated that the primary effect of gibberellins is associated with a significant increase in the number of cells dividing in the region directly below the subapical meristem, as well as leading to increased elongation of the interstitial cells, and that the apical mastermind works unaffected by the gibberellins and it appears that the effect of gibberellins. It is due to its regulation of enzymatic activity similar to the action of auxins although different enzymes are involved. Many proofs indicate that gibberellins stimulate growth by increasing metabolism as it increases soluble carbohydrates due to the activation of the alpha-amylase enzyme, which increases its activity dramatically when treatment with gibberellic acid and an increase in oxygen consumption as well as an increase in the accumulation of a number of other enzymes, and stated that its effect may be due to its role In stimulating the transfer of photosynthesis products from the leaf to the developing top.

\section{REFERENCES}

Abdul Jaleel, C. R.; Zhao, C.; Azooz, M. M. and panneerselvam, R. (2008). Plant growth regulators and fungicides Alters growth characteristics in catharanthus roseus comparative study. Global J. Moleclar Sci., 3(2): 93-99.

Abdul-Razzaq, T.; Khudair, Y; and Abdul-ALWahed, N.Y (2014). Effect of pinching and spraying with gibberellic acid and zinc on growth vegetative and flowering and root of plant Geranium Pelargonium hortorum L. Kufa J. Agric. Sci., 6 (2): 1-19.

Abu Zaid, A.N. (2000). Plant hormones and agricultural applications. Arab Publishing House. Cairo University.

Al-Khuzaai, Z.H.TH. (2013). Study of the effect of growth regulator gibberellin $\mathrm{GA}_{3}$ and liquid organic fertilizer GROWMAX on some vegetative and flower growth characteristics of Tagetes erecta L. Scientific J. Karbala, 1 (11): 119-125.

Al-Layla, M.A. (2006). Effect of shading, gibberellic acid and micronutrints on some chemic composition characters of Indian rubber plant Ficus elastica Roxb. var. decora. Ph.D. Thesis, College of Agriculture and Forestry, University of Mosul. Ministry of Higher Education and Scientific Research. The Republic of Iraq.

AL-sahin, J.H.A. (2011). Effect of spraying with gibberellic acid and indol -3-acetic acid concentrations on vegetative and flowering growth parameters of carnation Dianthus caryophyllus L. Master Thesis, Agriculture College, University of Kufa Republic of Iraq.

Bidwell, R.G.S. (1979). Plant Physiology. $2^{\mathrm{d}}$ ed., Collier Maclmillan Canada.

Emongor, V.E. (2003). Effects of gibberellic acid $\left(\mathrm{GA}_{3}\right)$ on postharvest quality and vase life of gerbera cut-flowers Gerbera jamesonii. African Crop Sci. Soc., 6: 541546.

Gurgar, H.M.M. (1996). Physiological study in ornamental plants. Master Thesis. Agriculture College. Egypt Republic.

Hopkins, W. G. (1999). Introduction to plant physiology (2 ${ }^{\text {nd }}$ Edi). John Wiley and Sons, Inc.

Hussein, A.M. (1979). Introduction in plant physiology. Ministry of Higher Education and Scientific Research, Republic of Iraq. 
Khattab, M.; El-Torky, M.G.; Mostafa; M. M. and Reda, M.S.D. (2000b). Pretreatment of gladiolus Cormels to produce commercial yield. II- Effect of replanting the produced corms on the vegetative growth, flowering and corms production. Alexandria J. Agric. Res., 945: 201-219.

Khattab, M.; El-Torky, M.G.; Mostafa; M. M. and Reda, M.S.D. (2000a). Pretreatments of gladiolus Cormels to produce commercial yield: I- Effect of $\mathrm{GA}_{3}$, sea water and magnetic system on the growth and corms production. Alexandria J. Agric., Res., 45: 181-199.

Kumar, P., Naveen; Reddy, Y. N. and Chandrashekar, R. (2008). Effect of growth regulators on flowering and corm production in Gladiolus. Indian J. Hort., 65 (1).

Kurtar, E. S. and Ayan, A. K. (2005). Effects of gibberellic acid $\left(\mathrm{GA}_{3}\right)$ and indole3- acedic acid (IAA) on flowering, stalk elongation and bulb characteristics of tulip Tulipa gesnerianna var. Cassini. Pakistan J. Biological Sci., 8(2): 273-277.
Mishra, P. and Ashok, G. (2018). Effect of foliar application of gibberellic Acid $\mathrm{GA}_{3}$ concentrations and spraying frequencies on vegetative and floral attributes of China aster (Callistephus chinensis L.). Nees J. curr. Microbiol App. Sci., 7(1): 1889-1894.

Narong, C. (2004). Flower Forcing for cut flower production with special reference to Thailand. Au. J. T., 7(3): 137-144.

Saleh, M.M.S (1991). Physiology of growth and flowering organization. Ministry of Higher Education and Scientific Research. Salah AL-Din University.

Selim, S. M.; Hassan, S. and Badaway, M. (1993). Effect of $\mathrm{GA}_{3}$ on the growth and flowering of carnation. Zagig J. Agri. Res., 20 (1 B): 349-362.

Wasfi, A.A. (1995). Growth regulators and their use in agriculture. First Edition. Academic Library.

Yassin, B.T. (2001). Basics of Plant Physiology. College of science. Qatar University. 